\title{
PENINGKATAN KETERAMPILAN BERBICARA SISWA DENGAN METODE KOOPERATIF JIGSAW DI KELAS 4 SDN 1 JIMBUNG KLATEN
}

\author{
IMPROVING STUDENTS' SPEAKING SKILL \\ USING COOPERATIVE JIGSAW METHOD OF FOURTH GRADE \\ OF SDN 1 JIMBUNG KLATEN
}

\author{
Nugrananda Janattaka, Anik Ghufron \\ STKIP PGRI Tulungagung, Universitas Negeri Yogyakarta \\ nandahanduk@gmail.com, anikgh@telkom.net
}

\begin{abstract}
Abstrak
Penelitian ini bertujuan untuk meningkatkan keterampilan berbicara siswa dengan menerapkan metode Jigsaw. Penelitian ini merupakan penelitian tindakan kelas. Subjek penelitian ini adalah siswa kelas 4 yang berjumlah 32 siswa. Pengumpulan data dalam penelitian ini dilakukan melalui teknik observasi, dan dokumentasi. Instrumen yang digunakan dalam penelitian ini adalah lembar observasi guru, lembar obsrvasi siswa,dan dokumentasi. Data hasil observasi guru dan siswa dianalisis secara deskriptif kuantitatif. Indikator keberhasilan dalam penelitian ini yaitu ketuntasan belajar siswa dalam keterampilan berbicara mencapai $75 \%$. Penelitian ini menunjukan bahwa penggunaan metode jigsaw dapat meningkatkan keterampilan berbicara siswa kelas 4 SD Negeri 1 Jimbung Klaten. Dari aktivitas pratindakan sampai dengan Siklus II mengalami peningkatan. Persentase ketuntasan pada pratindakan, jumlah siswa yang tuntas sebanyak 16 siswa atau sebesar 50\%, kemudian mengalami peningkatan pada Siklus I menjadi 22 siswa dengan persentase ketuntasan sebesar 68\% dan pada Siklus II mengalami peningkatan menjadi 29 siswa dengan persentase 90,62\%.
\end{abstract}

Kata Kunci: keterampilan berbicara, metode jigsaw

\begin{abstract}
This study aims to apply the Jigsaw method to improve the speaking skill of fourth grade students. This was a classroom action research study. The research subjects were 32 Grade 4 students. The data were collected through observations, tests, documentation, and unstructured interviews. The research instruments consisted of a teacher activity observation sheet, a student activity observation sheet, documents, an interview guide, and learning achievement tests. The data from the teacher and students activity observations were analyzed using the quantitative descriptive technique. The data from the learning achievement tests were analyzed using the quantitative descriptive technique. The success indicator in this study is that the students' speaking skill improves if, in terms of the learning mastery in the speaking skill, on the whole the percentage of students achieves at $75 \%$. The results of the study show that the using jigsaw methods are capable of improving students' speaking skill. From the pretest before Cycle I to Cycle II the students' reading skill has improved. From the actions in Cycle I it is shown that in terms of the percentage of achievement on the pretest, the number of students who have completed the learning is as much as 16 or by 50\%, in Cycles I into the 22 students with the percentage of achievement as much as $68 \%$ and in Cycles Ii being 29 the students with the percentage of $90,62 \%$.
\end{abstract}

Keyword: jigsaw method, speaking skill 


\section{Pendahuluan}

Pembelajaran bahasa dan sastra Indonesia bertujuan untuk meningkatkan keterampilan berbahasa siswa. Oleh karena itu, pembelajaran bahasa dan sastra Indonesia perlu diarahkan untuk meningkatkan kemampuan siswa berkomunikasi dengan menggunakan bahasa Indonesia, baik secara lisan maupun tertulis.

Sesuai dengan tujuan tersebut, maka pembelajaran bahasa dan sastra Indonesia di sekolah-sekolah harus lebih ditingkatkan apalagi ditaraf sekolah dasar yang masih dalam tingkat awal pembentukan keterampilan berbahasa. Akan tetapi, berdasarkan hasil observasi di SD Jimbung 1 Klaten terdapat fenomena dimana siswa menunjukan kecenderungan sulit menerima pembelajaran terutama keterampilan berbicara. Selama ini pengajaran bahasa yang berlangsung di kelas-kelas adalah lebih banyak memberikan pengetahuan dan kaidah bahasa (stuktur) bukan keterampilan berbahasa.

Pembelajaran bahasa Indonesia terintegrasi dalam empat kemampuan berbahasa. Keempat kemampuan berbahasa tersebut, yaitu keterampilan menyimak (listening skill), keterampilan berbicara (speaking skill), keterampilan membaca (reading skill), keterampilan menulis (writing skill). Keempat kemampuan tersebut merupakan catur tunggal yang dilandasi oleh proses-proses berpikir yang mendasari kemampuan bahasa seorang individu. Kemampuan-kemampuan tersebut saling menunjang dan tidak terpisahkan. Dalam pembelajaran di kelas, keterampilan berbahasa tersebut diintegrasikan dalam satu kesatuan. Namun untuk kepentingan pembinaan keterampilan berbahasa siswa, masing-masing kemampuan berbahasa dapat dipilah sebagai fokus-fokus pembelajaran. Misalnya, untuk mengembangkan kemampuan berbicara para siswa, pembelajaran dapat dikonsentrasikan pada pengembangan keterampilan berbicara.

Keterampilan berbicara perlu dimiliki oleh setiap orang, khususnya siswa. Oleh karena itu, proses pembelajaran berbicara akan menjadi mudah jika peserta didik terlibat aktif berkomunikasi hal itu dikemukakan oleh Iskandarwassid dan Suhendar (2009, p.240). Semua pelajaran di sekolah pasti memanfaatkan kegiatan berbicara sebagai sarana transfer informasi dari guru ke siswa. Dalam dunia pendidikan, keterampilan berbicara merupakan salah satu aspek pembelajaran bahasa Indonesia yang masih perlu dicermati lagi dan diharapkan dapat menunjang pembinaan keterampilan berbahasa Indonesia. Tujuan pengajaran keterampilan berbicara di sekolah-sekolah adalah untuk mempersiapkan siswa agar mampu mengemukakan ide, gagasan, pikiran atau perasaannya secara lisan dengan baik.

Bahasa yang digunakan dalam percakapan pada dasarnya dipelajari lewat menyimak dan menirukan pembicaraan. Anak-anak tidak hanya menirukan pembicaraan yang mereka pahami, tetapi juga mencoba menirukan hal-hal yang tidak mereka pahami. Kenyataan ini mengharuskan orang tua dan guru menjadi model berbahasa yang baik supaya anak-anak tidak menirukan pembicaraan yang memalukan atau tidak benar. Dalam metode berbicara ditekankan pada kemampuan mengungkapkan pikiran atau isi hati secara lisan. Kegiatan ini sulit dilakukan karena berbicara yang baik memerlukan pendengaran yang baik pula. Keterampilan berbicara lebih mudah dikembangkan apabila peserta didik memperoleh kesempatan untuk mengkomunikasikan sesuatu secara alami kepada orang lain. Sesuai tujuan utama berbicara adalah untuk berkomunikasi, sebaiknya pembicara betul-betul memahami isi pembicaraannya. Hendaknya pendengar bersedia memahami dan menganggap apa yang didengarnya sehingga timbul hubungan timbal-balik aktif.

Usaha menjadikan kegiatan ini menjadi aktivitas yang hidup tidak terlepas dari persyaratan adanya pendengar yang baik. Pada kenyataannya di Sekolah Dasar Negeri 1 Jimbung Klaten kebanyakan siswa kelas 4 mengalami permasalahan dalam kemampuan berbicara. Berdasarkan observasi yang peneliti lakukan pada tanggal 5-7 September 2012 terdapat indikasi yang mengacu pada masalah kesulitan berbicara yang disebabkan oleh: (1) pasifnya siswa yang dikarenakan kurangnya kerja sama dalam proses pembelajaran keterampilan berbicara; (2) siswa merasa tidak percaya diri saat menyampaikan gagasan atau ide secara individual; (3) kurangnya interaksi antara siswa ke siswa atau siswa ke guru; (4) guru bukan sebagai teman bicara yang baik melainkan hanya sebagai penyampai materi; (5) siswa belum terbiasa untuk diajak mengungkapkan ide dan gagasan.

Dengan adanya masalah di atas dan setelah adanya penjelasan dari guru, diketahui bahwa nilai para siswa masih tergolong rendah dari nilai rata-rata yang harus dicapai untuk mata pelajaran bahasa Indonesia yang seharusnya 7,5 . 
Kebanyakan dalam proses belajar berbicara siswa takut untuk mengeluarkan pendapatnya, melalui penerapan metode kooperatif Jigsaw diharapkan siswa akan berani mengeluarkan pendapat, juga akan menambah kekompakan dalam bermusyawarah. Hal tersebut dapat diperkuat dari pendapat Roger dan Johnson (Lie, 2002, p.30) yang menyatakan pembelajaran kooperatif adalah suatu sistem yang di dalamnya terdapat elemen-elemen yang saling terkait. Adapun berbagai elemen dalam pembelajaran kooperatif adalah adanya (1) saling ketergantungan positif, (2) interaksi tatap muka, (3) akuntabilitas individual, dan (4) keterampilan untuk menjalin hubungan antara pribadi atau keterampilan sosial yang secara sengaja diajarkan.

Dalam model pembelajaran kooperatif jigsaw tugas guru tidak hanya sekedar mengupayakan para siswanya untuk memperoleh berbagai pengetahuan dan keterampilan. Lebih dari itu, guru harus dapat mendorong siswa untuk dapat bekerja secara kelompok dalam rangka menumbuhkan daya nalar, cara berpikir logis, sistematis, kreatif, cerdas, terbuka dan ingin tahu. Oleh karena itu, hal yang dibutuhkan guru dalam belajar adalah mengembangkan pengalaman-pengalaman belajar melalui pendekatan dan inovasi model-model pembelajaran atau pada sekarang ini biasa disebut dengan pembelajaran kooperatif.

Pembelajaran kooperatif jigsaw yang digunakan untuk melatih kemampuan berbicara, yaitu dengan banyak variasi kegiatan seperti percakapan, bericara estetik maupun penyampaian gagasan. Dengan banyaknya jenis kegiatan untuk pembelajaran keterampilan berbicara secara berkelompok diharapkan siswa dapat mengeluarkan suara dan pendapatnya, siswa pun mempunyai tanggung jawab atas bagianbagian dari kegiatan berbicara. Karena keberhasilan kelompok sangat tergantung pada usaha setiap anggotanya, dengan kegiatan tersebut diharapkan dapat mencapai tujuan pembelajaran berbicara sesuai dengan yang direncanakan.

Berdasarkan latar belakang di atas, penulis mencoba memecahkan masalah tersebut dengan mengajukan judul "Peningkatan Keterampilan Berbicara Siswa dengan Metode Kooperatif Jigsaw di Kelas 4 SDN 1 Jimbung Klaten"

Perumusan masalah yang penulis ajukan dalam penelitian ini adalah: "Apakah keterampilan berbicara dapat ditingkatkan dengan menggunakan pendekatan kooperatif tipe jig- saw di kelas 4 SDN 1 Jimbung Klaten ?". Sehingga penelitian ini memiliki tujuan untuk: "Meningkatkan keterampilan berbicara siswa SD kelas 4 SDN 1 jimbung Klaten melalui metode kooperatif tipe jigsaw".

\section{Metode}

Jenis Penelitian

Jenis penelitian ini adalah Penelitian Tindakan Kelas (Classroom Action Research). Penelitian Tindakan Kelas sebagai bentuk penelitian reflektif yang dilakukan oleh guru yang hasilnya dapat dimanfaatkan sebagai alat untuk mengembangkan kurikulum, pengembangan sekolah, pengembangan keahlian mengajar, meningkatkan kemampuan siswa dan sebagainya.

Desain Penelitian

Penelitian Tindakan Kelas ini dilaksanakan dalam bentuk siklus terdiri dari perencanaan, pelaksanaan, observasi, dan refleksi. Desain PTK berbentuk siklus-siklus. Satu siklus terdiri atas empat fase, yaitu, (1) fase perencanaan (planning), (2) fase pelaksanaan (action), (3) fase observasi/ pemantauan (observation), dan (4) fase refleksi (reflection).

Adapun penjelasan dari fase-fase tersebut adalah sebagai berikut:

\section{Fase Perencanaan (Planning)}

Pada siklus pertama, perencanaan tindakan (planning) dikembangkan berdasarkan hasil observasi awal. Dari masalah yang ada dan cara pemecahannya yang telah ditetapkan, dibuat perencanaan kegiatan belajar mengajarnya $(\mathrm{KBM})$. Perencanaan ini persis dengan KBM yang dibuat oleh guru sehari-hari, termasuk penyiapan media, dan alat-alat pemantauan perkembangan pengajaran seperti lembar observasi, tes, catatan harian, dan lain-lain.

\section{Fase Pelaksanaan (Action)}

Fase ini adalah pelaksanaan KBM yang telah direncanakan. Bersamaan dengan ini dilakukan juga fase observasi/pemantauan. Dimana akan diterapkannya metode jigsaw saat pembelajaran berlangsung. Pelaksanaan tindakan dalam penelitian ini dilakukan sesuai dengan langkah-langkah pembelajaran yaitu: (a) kegiatan awal, (b) kegiatan inti, (c) kegiatan akhir.

\section{Fase Observasi/pemantauan (Observation)}

Dalam fase observasi, dilakukan beberapa kegiatan seperti pengumpulan data-data yang diperlukan. Untuk mendapat data ini, 
diperlukan instrumen dan prosedur pengumpulan data (dibahas oleh pemakalah lain). Dalam fase ini juga dilakukan analisis terhadap data, dan interpretasinya. Fase ini berlangsung bersamaan dengan pelaksanaan tindakan (action), dan pada akhir tindakan. Data yang diambil selama pelaksanaan tindakan misalnya observasi perilaku siswa. Pada akhir tindakan dapat dilakukan tes maupun wawancara.

\section{Fase Refleksi (Reflection)}

Fase ini terdiri atas refleksi kritis dan refleksi diri. Refleksi kritis adalah pemahaman secara mendalam atas temuan siklus tersebut, dan refleksi diri adalah mengkaji kelebihan dan kekurangan yang terjadi selama siklus berlangsung. Dengan demikian, fase ini berisi kegiatan pemaknaan hasil analisis, pembahasan, penyimpulan, dan identifikasi tindak lanjut. Hasil identifikasi tindak lanjut selanjutnya menjadi dasar dalam menyusun fase perencanaan (planning) siklus berikutnya.

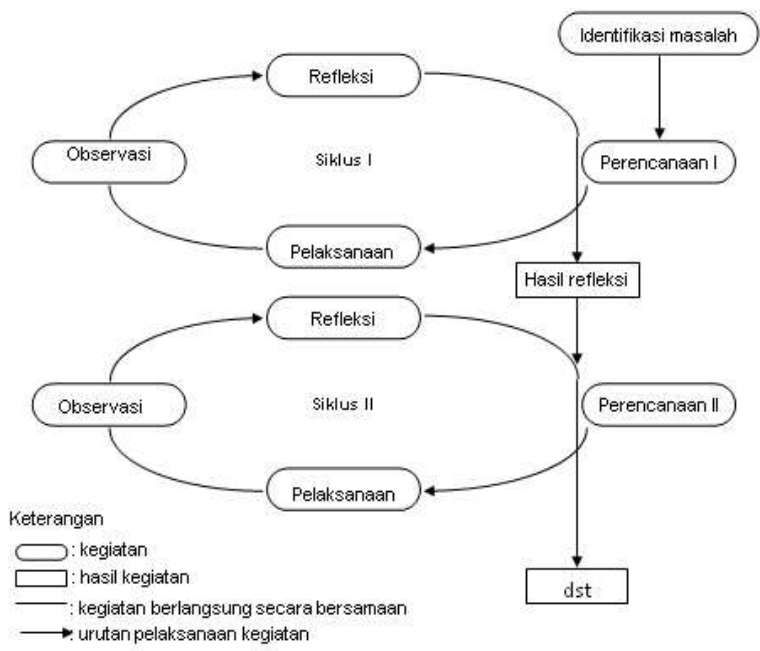

Gambar 1. Siklus Model Spiral Kemmis \& Taggart (1993, p.32)

Waktu dan Tempat Penelitian

Tempat yang akan digunakan untuk melakukan penelitian ini adalah SD Jimbung 1 Klaten. Waktu penelitian dilakukan selama 2 bulan, yaitu dari bulan Agustus sampai September 2012.

Target/Subjek Penelitian

Penelitian ini dilakukan di sekolah dasar dan adapun subjeknya adalah siswa kelas 4 SD Jimbung 1 Klaten, dan yang dijadikan kolaborator adalah guru kelas $4 \mathrm{SD}$.
Data, Teknik Pengumpulan Data dan Instrumen

Sumber data dalam penelitian ini adalah:

\section{Tempat dan Peristiwa}

Sumber data penelitian ini adalah proses belajar keterampilan berbicara yang berlangsung di kelas dan dialami oleh siswa kelas IV SD.

\section{Informan}

Informan dalam penelitian ini adalah Guru Bahasa dan Sastra Indonesia kelas IV serta siswa kelas IV, karena dalam kelas ini pembelajaran keterampilan berbicara masih tergolong rendah.

\section{Dokumen}

Dokumen, yaitu bahan tertulis atau benda yang berkaitan dengan suatu peristiwa atau aktivitas tertentu. Sumber data ini digunakan untuk mengetahui bagaimana bentuk perencanaan guru dalam pembelajaran keterampilan berbicara di kelas IV SD. Dokumen yang dijadikan sumber data berupa: buku paket bahasa Indonesia , lembar hasil observasi, daftar nilai, serta hasil wawancara.

\section{Teknik Pengumpulan Data}

Untuk memperoleh informasi data yang representatif dan signifikan dari proses dan aktifitas pebelajaran serta situasi lain yang mempengaruhinya maka peneliti menggunakan beberapa teknik dalam pengumpulan data sebagai berikut:

\section{Teknik Pengumpulan Data Tentang Proses Pembelajaran Keterampilan Berbicara.}

\section{a. Observasi}

Pengamatan dilakukan mulai dari awal kegiatan pembelajaran yang berkaitan dengan proses menulis di kelas IV SDN 1 Jimbung Klaten. Dengan demikian, ativitas guru dan perilaku siswa pada saat proses pembelajaran menulis dicatat dalam lembar observasi dan di interpretasikan untuk mendapatkan data penelitian.

\section{b. Analisis Dokumen}

Analisis dokumen bermanfaat untuk melengkapi dan memperjelas hasil informasi. Dalam penelitian ini teknik yang dilakukan adalah analisis dokumen dengan cara mengamati, mencatat dan mengumpulkan dari apa 
yang tersirat dan tertulis dalam setiap dokumen atau arsip yang menjadi sumber data.

Moleong (2002, p.16) menyatakan bahwa "dokumen adalah setiap bahan tertulis ataupun film". Dengan demikian metode ini untuk mencari data mengenai hal-hal yang berkaitan dengan permasalahan penelitian dengan melihat atau meneliti dokumen tersebut.

\section{Teknik Pengumpulan Data Tentang Hasil Belajar Keterampilan Berbicara}

Teknik yang digunakan adalah pemberian tes. Tes digunakan untuk mengetahui perkembangan atau keberhasilan pelaksanaan tindakan. Adapun bentuk tes yang diberikan adalah tes lisan (berbicara di depan kelas bergantian secara kelompok).

Instrumen Penelitian

Penelitian tindakan kelas ini menggunakan beberapa instrumen penelitian sebagai berikut:

\section{Lembar Observasi}

a. Lembar observasi guru

Lembar observasi ini dikembangkan berdasarkan indikator-indikator yang telah ditentukan. Pemerolehan data dilakukan melalui observasi untuk mengetahui keefektifan pembelajaran selama proses pembelajaran menulis dengan metode Cooperative Jigsaw. Data hasil observasi aktivitas guru nantinya akan disajikan secara naratif berupa deskripsi data kualitatif hasil observasi.

\section{b. Lembar observasi siswa}

Pemerolehan data dilakukan melalui observasi untuk mengetahui keaktifan siswa selama proses pembelajaran menulis dengan pendekatan proses dan media gambar. Data hasil observasi aktivitas siswa nantinya akan disajikan secara naratif berupa deskripsi data kualitatif hasil observasi.

c. Tes unjuk kerja

Tes yang digunakan dalam penelitian ini adalah tes verbal berupa praktik berbicara secara langsung. Tes yang diberikan adalah unjuk kerja dan bertelepon.

Teknik Analisis Data

Teknik analisis data dalam penelitian tindakan kelas ini meliputi teknik kuantitatif dan teknik kualitatif. Teknik kuantitatif digunakan untuk menganalisis data kuantitatif. Data kuantitatif ini diperoleh dari hasil tes berbicara dengan pembelajaran kooperatif metode jigsaw pada siklus I dan siklus II. Hasil nilai tiap-tiap tes dihitung rata-ratanya dengan menggunakan rumus sebagai berikut:

$$
\mathrm{NP}=\frac{\sum \mathrm{N}}{\mathrm{n} \times \mathrm{s}} \times 100 \%
$$

NP : Nilai dalam persen

$\Sigma \mathrm{N} \quad$ : Jumlah nilai siswa dalam satu kelas

$\mathrm{n} \quad$ : Nilai maksimum

s : Banyaknya siswa dalam satu kelas

Data kualitatif meliputi data observasi, jurnal, wawancara, dan dokumentasi. Analisis dilakukan dengan cara memadukan antardata secara keseluruhan. Hasil analisis tersebut untuk mengetahui siswa yang mengalami kesulitan dalam berbicara, kelebihan dan kekurangan pembelajaran berbicara menggunakan pembelajaran kooperatif metode jigsaw, dan juga sebagai dasar melakukan perbaikan selanjutnya.

Indikator Keberhasilan

Indikator keberhasilan dalam penelitian tindakan kelas ini adalah: "Keterampilan berbicara siswa dikatakan meningkat jika ketuntasan belajar siswa dalam keterampilan berbicara secara klasikal siswa mencapai 75\%. Dikarenakan Target Ketuntasan Nasional yang ditargetkan pemerintah berada pada capaian kkm 75\%".

\section{Hasil Penelitian dan Pembahasan}

Prosedur Penelitian

Penelitian ini dilaksanakan dalam dua siklus. Untuk mendapatkan gambaran awal pelaksanaan pembelajaran keterampilan berbicara, peneliti melakukan kegiatan survei awal. Kegiatan survei awal ini dimaksudkan untuk mengetahui keadaaan awal yang ada di lapangan mengenai pembelajaran keterampilan berbicara. Pemahaman akan kondisi awal dari kegiatan survei awal ini menjadi dasar untuk menentukan tindakan yang relevan untuk mengatasi permasalahan pembelajaran yang dialami guru maupun siswa, khususnya pembelajaran berbicara. Peneliti melakukan kegiatan observasi pengamatan kelas, wawancara dengan guru kelas dan siswa. Survei dilaksanakan pada hari Sabtu, 3 Oktober 2012 untuk melihat proses pembelajaran keterampilan berbicara siswa Kelas IV SDN I Jimbung Klaten. Hasil dari kegiatan survei awal penelitian ini adalah sebagai berikut: 


\section{Kemampuan Bahasa Lisan Siswa}

Hasil wawancara dengan guru menyebutkan hanya 28,94\% (11 Siswa) dari 32 siswa yang dinilai sudah terampil berbicara dalam situasi formal di depan kelas. Sebagian siswa masih merasa takut, malu, dan kurang berminat untuk tampil di depan kelas.

\section{Siswa tidak Antusias dalam Mengikuti Pembel- ajaran Keterampilan Berbicara}

Survei awal menunjukkan bahwa sikap siswa kurang peduli pada saat pembelajaran berbicara berlangsung. Siswa terllihat pasif saat pembelajaran berlangsung. Nampak beberapa siswa memperhatikan penjelasan guru, namun tak sedikit pula siswa yang ramai sendiri mengobrol dengan temannya, bahkan ada siswa yang sibuk sendiri melakukan aktivitas di luar pembelajaran misalnya mengerjakan tugas dari mata pelajaran lain dan membaca buku selain buku pegangan bahasa Indonesia.

\section{Siswa tidak Berani dan Kurang Percaya Diri Tampil di Depan Kelas.}

Pengamatan peneliti terhadap proses pembelajaran berbicara yang dilakukan guru, kenyataan dilapangan banyak siswa yang tidak mau tampil di depan kelas dikarenakan siswa kurang percaya diri, siswa malas berbicara sehingga siswa ogah-ogahan tampil di depan kelas, dan juga siswa malu dan takut salah berbicara di depan kelas. Kurangnya minat dan malas untuk berlatih berbicara menyebabkan siswa tidak mau tampil di depan kelas.

\section{Guru Kesulitan dalam Membangkitkan Minat Siswa}

Berdasarkan pengamatan peneliti selama proses pembelajaran berbicara, siswa menunjukkan kurang antusias terhadap proses pembelajaran yang sedang berlangsung. Sikap guru pun terlihat kurang memperhatikan siswa yang ramai sendiri, guru bersikap tegas disaat siswa melakukan kesalahan yang berlebihan yaitu disaat siswa mengeluarkan kata-kata yang kurang sopan pada temannya.

\section{Guru Kurang Kooperatif Saat Pembelajaran Berlangsung}

Berdasarkan pengamatan peneliti, menunjukkan kurangnya komunikasi aktif dengan siswa. Hal itu ditunjukkan dengan adanya siswa yang mengalihkan perhatian saat pembelajaran berbicara berlangsung. Saat pembelajaran berlangsung guru lebih banyak berdiri di depan kelas, ini menyebabkan sebagian siswa tidak memperhatikan pembelajaran. Saat guru meminta siswa untuk tampil di depan kelas tidak ada satu pun siswa yang mau untuk tampil, walaupun guru langsung menunjuk siswa, siswa tetap tidak bersedia.

Guru Kesulitan dalam Mengembangkan Model Pembelajaran yang Tepat untuk Mengajarkan Materi Keterampilan Berbicara

Selama ini pembelajaran keterampilan berbicara lebih banyak didominasi dengan materi, sehingga siswa kurang berlatih untuk berbicara di depan kelas. Guru sudah menggunakan metode yang sesuai dengan pembelajaran berbicara yaitu dengan metode sesama anggota kelompok terstruktur. Berdasarkan hasil pengamatan peneliti guru tidak sepenuhnya menggunakan metode sesama anggota kelompok terstruktur, guru lebih banyak ceramah dan tanya jawab dengan siswa.

\section{Ditinjau dari Segi Lingkungan saat KBM Keterampilan Berbicara}

Survei awal tampak bahwa pembelajaran berbicara masih kurang efektif. Terdapat beberapa siswa yang kurang serius mengikuti pembelajaran. Hal ini terlihat saat siswa tampil di depan kelas dengan menggunakan bahasa yang kurang sesuai dan terdengar kurang lancar, ada beberapa siswa yang menertawakan dan melontarkan kata-kata yang kurang sopan. Bahkan ada sebagian siswa yang mondar-mandir tanpa memperhatikan kegiatan pembelajaran berbicara, ini menyebabkan kelas menjadi gaduh.

\section{Proses Pelaksanaan KBM Keterampilan Berbicara}

Berdasarkan pengamatan peneliti pada survei awal, proses pembelajaran keterampilan berbicara belum mencapai tujuan pembelajaran. Aktivitas proses pembelajaran dinilai dari perhatian, keberanian tampil di depan kelas, kerja sama, dan kemapuan siswa berbicara dengan menggunakan bahasa Indonesia yang runtut, baik, dan benar. Berdasarkan seluruh aspek penilaian tersebut diperoleh data yaitu berupa presentase keberhasilan 28,94\% (11 siswa) dari keseluruhan siswa (32 siswa).

Hasil Penelitian

Tahap selanjutnya adalah proses penelitian dilaksanakan dalam 2 siklus yang masingmasing siklus terdiri dari 4 tahapan, yakni: (1) 
perencanaan, (2) pelaksanaan tindakan, (3) observasi dan interpretasi, (4) analisis dan refleksi.

Secara garis besar hasil penelitian ini disajikan dalam tabel berikut ini:

Tabel 1. Perbandingan Nilai Keterampilan Berbicara Siswa Pratindakan, Siklus I, dan Siklus II

\begin{tabular}{cccccc}
\hline \multirow{2}{*}{ No } & Nilai & \multicolumn{3}{c}{ Jumlah Siswa } & \\
\cline { 3 - 5 } & & Pra & SK I & SK II & \\
\hline 1 & $\geq 80$ (Sangat Baik) & 5 & 10 & 17 & T \\
2 & $70-79$ (Baik) & 11 & 12 & 12 & T \\
3 & $60-69$ (Cukup) & 13 & 9 & 3 & BT \\
4 & $50-59$ (Kurang) & 3 & 1 & 0 & BT \\
5 & $0-49$ (Sangat Kurang) & 0 & 0 & 0 & BT \\
& Nilai $\leq 75$ & 16 & 10 & 3 & \\
& Nilai $\geq 75$ & 16 & 22 & 29 & \\
\hline
\end{tabular}

Tabel 1 menunjukkan bahwa terjadi peningkatan nilai keterampilan berbicara: bertelpon di siklus II yaitu sebesar $21,87 \%$. Adapun perinciannya adalah pada pratindakan nilai $\leq 75$ sebanyak 16 siswa sedangkan pada siklus I menurun menjadi 10 siswa. Kemudian pada siklus II turun menjadi 3 siswa. Nilai $\geq 75$ didapat oleh 16 siswa pada pratindakan dan mengalami kenaikan pada siklus I yaitu sebanyak 22 siswa. Kemudian pada siklus II naik menjadi 29 siswa. Persentase ketuntasan pembelajaran berbicara: bertelepon pratindakan sebesar 50\% sedangkan pada siklus I sebesar 69\%. Pada siklus II ketuntasan akhirnya adalah 91\%. Jadi, dapat disimpulkan bahwa peningkatan persentase ketuntasan siswa dari siklus I ke siklus II adalah sebesar $21,87 \%$. Perincian perbandingan nilai siswa dalam pembelajaran berbicara pada siklus II kelas IV SDN I Jimbung Klaten dapat dilihat pada gambar diagram batang berikut:

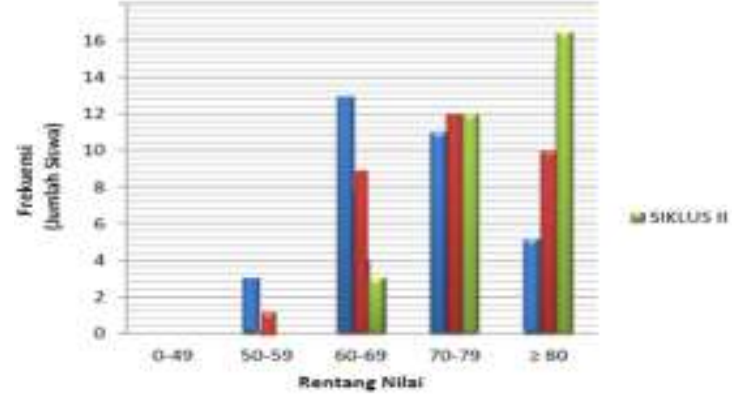

Gambar 2. Diagram Perbandingan Nilai Keterampilan Berbicara Siswa Pratindakan, Siklus I dan Siklus II
Berdasarkan observasi dan evaluasi pelaksanaan siklus II, proses pembelajaran berbicara: bertelepon dengan menggunakan teknik jigsaw dikelas IV ini berjalan sesuai rencana pembelajaran dan berjalan lancar. Keaktifan siswa dalam pembelajaran, keberanian siswa tampil di depan kelas, keaktifan dalam bekerjasama dengan sesama anggota kelompok, dan keterampilan berbicara: bertelepon menunjukkan peningkatan. Siswa mampu memahami meteri yang disampaikan guru dengan baik. Siswa dapat mengembangkan kemampuan imajinasi dan kreatifitas dengan baik. Kekurangan-kekurangan yang dialami pada pratindakan dan siklus I mampu teratasi pada siklus II. Secara kualitas, baik keaktifan/proses maupun keterampilan berbicara menunjukkan peningkatan.

Berdasarkan observasi yang dilakukan peneliti menunjukkan bahwa ada peningkatan proses dan hasil yang cukup signifikan dari siklus sebelumnya. Akan tetapi masih ada beberapa fakta yang menunjukkan bahwa ada kekurangan dalam pembelajaran berbicara tersebut. Fakta-fakta tersebut antara lain: (1) ada siswa yang kurang aktif dalam pembelajaran, yaitu sebesar 25 siswa (78\%) yang ditunjukkan dengan mengobrol dengan temannya, mengerjakan pekerjaan lain, mengantuk, mengganggu teman lain, dan tidak memperhatikan penjelasan guru, (2) siswa belum berani tampil di depan kelas, yaitu sebesar 23 siswa (71\%) yang ditunjukkan dengan tidak mengambil inisiatif tampil dengan keinginan sendiri, siswa masih harus ditunjuk untuk tampil di depan kelas dan (3) siswa kurang aktif dalam bekerja sama dengan sesama anggota kelompok, yaitu sebesar 24 siswa (75\%) yang ditunjukkan dengan tidak fokus saat berdiskusi, tidak memberikan komentar atau penilaian saat rekannya latihan berbicara, kurang serius (bermain) ketika latihan maupun praktik berberbicara, (4)ada 3 siswa (9\%) yang belum tuntas dalam pembelajaran berbicara dengan ketuntasan 75 .

Berkaitan dengan fakta-fakta mengenai kekurangan pembelajaran tersebut, peneliti dan guru melakukan refleksi dengan hasil sebagai berikut: (1) ada siswa yang kurang memerhatikan ketika pembelajaran berbicara: bertelepon berlangsung dikarenakan kurang fokus terhadap pembelajaran dan beraktivitas sendiri, (2) ada siswa yang masih sulit untuk mengembangkan imajinasi terhadap tema yang diberikan guru, (3) ada beberapa siswa yang belum aktif berdiskusi, latihan berbicara, dan praktik berbicara, (4) ada siswa yang belum mencapai batas ke- 
tuntasan minimal disebabkan kurang memerhatikan dan kurang serius ketika pembelajaran berbicara berlangsung. Namun, secara keseluruhan menunjukkan bahwa pemakaian teknik jigsaw pada siswa kelas IV SDN I Jimbung Klaten, dapat meningkatkan kualitas proses berupa keaktifan siswa dan hasil berupa keterampilan berbicara: bertelepon dengan kalimat efektif dan bahasa yang santun.

Pembahasan

Keterampilan berbicara merupakan keterampilan memproduksi melalui sistem bunyi artikulasi untuk menyampaikan kehendak, kebutuhan, perasaan, dan keinginan-keinginan pada orang lain. (Tarigan, 2008, p.16) Berbicara adalah berkata, bercakap-cakap, berbahasa, melahirkan pendapat (dengan perkataan, tulisan, dan sebagainya).

Untuk dapat berbicara dalam suatu bahasa secara baik, pembicara harus menguasai lafal, struktur, dan kosakata yang bersangkutan. Di samping itu, diperlukan juga penguasaan masalah dan atau gagasan yang akan disampaikan, serta kemampuan bahasa lawan bicara. Selain dapat menginformasikan sesuatu dan menyampaikan pikirannya dalam kegiatan berbicara, juga diharapkan untuk mampu mengajukan pertanyaan kepada lawan bicaranya atau kepada orang lain (Nurgiyantoro, 2001, p.276).

Zuchdi dan Budiasih (1996, p.33) menjelaskan, ada beberapa pendekatan pembelajaran bahasa yang di antaranya adalah pendekatan komunikatif, yaitu pendekatan yang dilandasi oleh pemikiran bahwa kemampuan menggunakan bahasa dalam komunikasi merupakan tujuan yang harus dicapai dalam pembelajaran bahasa. Pendekatan ini berusaha menempatakan fungsi bahasa sebagai fungsi komunikatif. Hal ini berarti pembelajaran bahasa memiliki tujuan agar pembelajar mampu menggunakan dan menerapkan bahasa secara tepat dalam suatu kegiatan komunikasi. Salah satunya bisa dengan pendekatan komunikatif dengan metode pembelajaran kooperatif khususnya pembelajaran tipe jigsaw.

Pembelajaran Kooperatif merupakan strategi berkelompok yang menuntut siswa bekerja sama untuk memperoleh keuntungan potensi belajar setiap siswa. Untuk memperoleh hasil yang maksimal dalam pembelajaran kooperatif harus memperhatikan hal-hal berikut: (1) setiap siswa harus memperhatikan perannya di dalam kelompok; (2) pola hubungan yang interaktif diantara kelompok; (3) akuntabilitas kelompok dan individu; (4) anggota memiliki kemampuan kepemimpinan dan interpersonal; (5) kemampuan untuk merefleksikan pembelajaran pribadi dan fungsi kelompok. (Smaldino, 2007, p.29)

Dalam proses pembelajaran di kelas 4 SDN 1 Jimbung Klaten ini, metode pendekatan kooperatif tipe jigsaw diterapkan pada materi menyampaikan pesan lewat telepon. Kebanyakan siswa memiliki kesempatan untuk menggunakan telepon untuk urusan pribadi mereka. Karena telepon sudah sangat luas digunakan sebagai media informasi, untuk permintaan, diskusi, undangan atau ketidakhadiran, para siswa mendapatkan keuntungan dari keahlian dalam bertelepon. Sebagaimana anak bermain dengan telepon mainan dan sebagaimana mereka menggunakan telepon di sekolah untuk membuat panggilan.

Guru bisa menemukan selama observasi dan diskusi bahwa para siswa membutuhkan bimbingan lebih lanjut terkait materi seperti: (1) bagaimana menggunakan telepon yang benar; (2) bagaimana memformulasikan pesan, permintaan, keinginan, dan informasi sebelum mengangkat telepon; (3) bagaimana menjelaskan siapa yang menelpon dan tujuan dari bertelepon itu sendiri; (4) bagaimana menangkap ide-ide seseorang secara benar dan tepat; (5) bagaimana menutup percakapan atau diskusi secara benar; (6) bagaimana menggunakan suara dengan sopan selama menelepon; (7) bagaimana mencermati pesan secara akurat; (8) bagaimana membuat suara yang bebermakna.

Siswa harus belajar pengalaman secara langsung seni bertelepon, akan tetapi berdasarkan ketercapaian observasi, membaca, diskusi dan drama, bimbingan guru bias diberikan sehingga kenyamanan dalam belajar bisa menjadi lebih menguntungkan kepada siswa dalam kemampuan berbicara Dengan demikian penerapan metode jigsaw ini dapat membantu siswa kemampuan berbicara dengan menggunkan bahasa Indonesia, karena selain mempunyai tanggung jawab memberikan pengertian terhadap anggota kelompok lain, metode ini juga melatih kepiawaian siswa dalam berkomunikasi menggunakan bahasa Indonesia, yaitu di mana siswa mengalami kemajuan dalam mempraktekkan penggunaan bahasa Indonesia yang baik terutama dalam hal komunikasinya yang banyak dilakukan selama proses pembelajaran, baik dengan guru ataupun dengan siswa-siswa lain. Serta, siswa sudah mampu mengenali tentang apa yang akan dibicarakan, siapa yang menjadi 
lawan bicaranya serta untuk apa hal itu dibicarakan. Dengan demikian siswa secara teoritis sudah melakukan proses komunikasi aktif dalam pembelajaran.

Dengan melihat hasil penelitian di atas dapat diketahui adanya peningkatan pembelajaran terutama keterampilan berbicara siswa setelah menggunakan model kooperatif tipe jigsaw. Peningkatan terlihat dari hasil perhitungan nilai hasil keterampilan berbicara yang diperoleh siswa pada kondisi awal (prasiklus) dan setelah dilaksanakan tindakan siklus I dan siklus II. Hal ini dapat dilihat dari Tabel 2 sebagai berikut:

Tabel 2. Rekapitulasi Ketercapaian Indikator Penelitian Siklus I Dan Siklus II

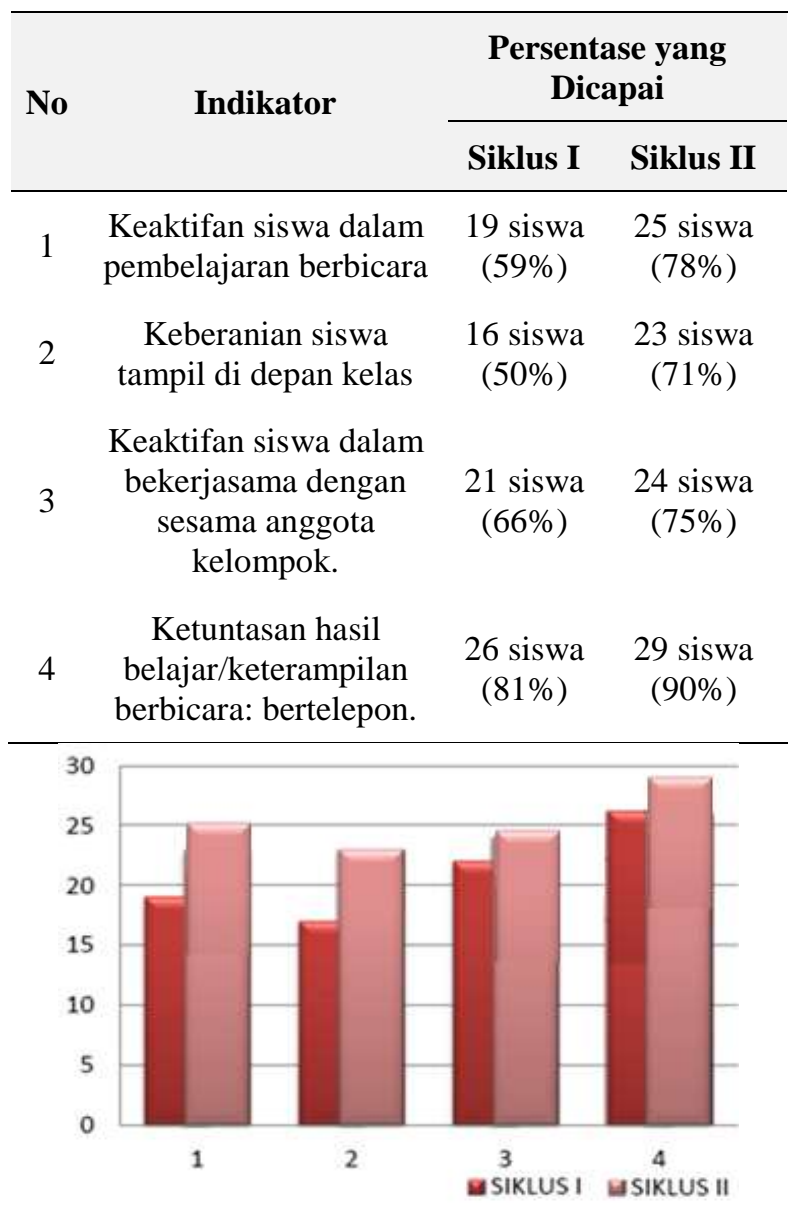

Gambar 3. Diagram Rekapitulasi Ketercapaian Indikator Penelitian Siklus I dan II

Keterangan:

1. Keaktifan dalam mengikuti pembelajaran berbicara

2. Keberanian siswa tampil di depan kelas

3. Keaktifan siswa melakukan kerja sama dengan sesama anggota kelompok

4. Keterampilan berbicara: bertelepon
Dari tabel dan diagram di atas tampak bahwa terjadi peningkatan baik dalam kualitas proses maupun hasil. Adapun perinciannya adalah sebagai berikut:

Pertama, meningkatkan keaktifan siswa dalam pembelajaran berbicara: bertelepon. Keaktifan siswa dalam pembelajaran semakin meningkat dari siklus I ke siklus II. Pada siklus I keaktifan siswa pada pembelajaran berbicara sebesar 59\% atau 19 siswa. Sedangkan pada siklus II sebesar $78 \%$ atau 25 siswa. Berarti keaktifan siswa dalam pembelajaran berbicara: bertelepon mengalami peningkatan sebesar $13,33 \%$. Keaktifan tersebut ditunjukkan dengan memperhatikan penjelasan guru, mengerjakan apa yang diperintahkan guru, melaksanakan diskusi, mengajukan pertanyaan, dan lain-lain.

Kedua, meningkatkan keberanian siswa tampil praktik bertelepon di depan kelas Keberanian siswa praktik bertelepon di depan kelas mengalami peningkatan dari siklus I ke siklus II. Pada siklus I keberanian siswa tampil di depan kelas pada pembelajaran berbicara sebesar $50 \%$ atau 16 siswa. Sedangkan pada siklus II sebesar $71 \%$ atau 23 siswa. Berarti keberanian siswa dalam pembelajaran berbicara: bertelepon mengalami peningkatan sebesar $20 \%$. Keberanian siswa tersebut ditunjukkan dengan adanya siswa yang dengan kesadaran sendiri untuk tampil praktik bertelepon di depan kelas, serta sikap yang ditunjukkan ketika praktik bertelepon.

Ketiga, meningkatkan keaktifan siswa dalam dalam bekerja sama dengan sesama anggota kelompok. Hal yang sama juga terjadi pada keaktifan siswa dalam bekerjasama dengan sesama anggota kelompok. Pada poin ini mengalami kenaikan. Pada siklus I 21 siswa atau $66 \%$ aktif bekerjasama dengan sesama anggota kelompok, sedangkan pada siklus II 24 siswa atau $75 \%$. Jadi, meningkat sebesar $9 \%$. Keaktifan dalam bekerjasama dengan sesama anggota kelompok ditunjukkan dengan aktif berdiskusi dalam membuat tulisan simulasi bertelepon, dan mampu bekerja sama dengan maksimal ketika tampil berbicara di depan kelas.

Keempat, meningkatkan ketuntasan hasil belajar berbicara: bertelepon. Pada siklus I ketuntasan hasil berbicara: bertelepon hanya 26 siswa $(81 \%)$. Mengalami peningkatan pada siklus II, yaitu mencapai 29 siswa (90\%). Jadi, meningkat sebesar 9\%. Ketuntasan tersebut ditandai dengan berhasil mencapai nilai $\geq 75$, 
yang merupakan KKM di SDN I Jimbung Klaten.

Dari data tabel rekapitulasi ketuntasan belajar siswa Kelas IV SDN I Jimbung Klaten pada prasiklus, siklus I dan siklus II di atas dapat dibuat grafik pada gambar 4 sebagai berikut:

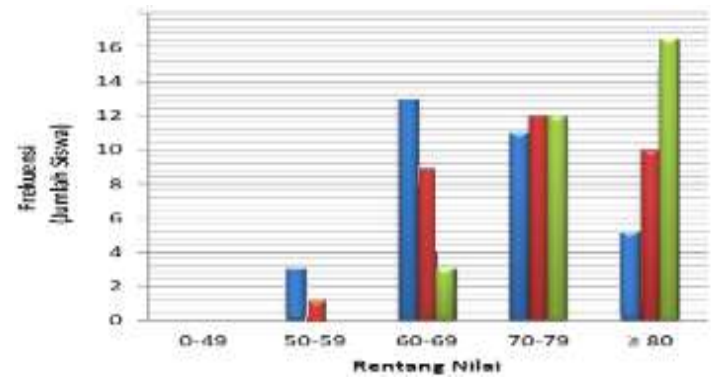

Gambar 4. Diagram Perbandingan Nilai

Keterampilan Berbicara Siswa Pratindakan,

Siklus I, dan Siklus II

Hasil penelitian tindakan kelas untuk meningkatkan keterampilan berbicara menggunakan model kooperatif tipe jigsaw yang dilakukan sebanyak 2 siklus ini mengalami peningkatan dan telah mencapai batas sesuai dengan indikator kinerja yang telah ditetapkan. Dengan demikian penelitian tindakan kelas yang dilaksanakan telah sesuai tujuan yang diharapkan, yakni dapat meningkatkan keterampilan berbicara.

Setelah mengolah data hasil keterampilan berbicara pada siswa kelas IV SDN I Jimbung Klaten, peneliti juga melakukan perhitungan skor perolehan kelompok Siklus I dan II. Adapun skor perolehan tiap kelompok jigsaw lebih jelasnya dapat disajikan dalam bentuk Tabel 3 berikut:
Tabel 3. Perbandingan Hasil Siklus I dan Siklus II

\begin{tabular}{|c|c|c|c|c|}
\hline \multirow[b]{2}{*}{ Klmp } & \multicolumn{2}{|c|}{ Siklus I } & \multicolumn{2}{|c|}{ Siklus II } \\
\hline & $\begin{array}{l}\text { Skor } \\
\text { Rata- } \\
\text { rata I }\end{array}$ & $\begin{array}{c}\text { Penghargaan } \\
\text { Kelompok }\end{array}$ & $\begin{array}{l}\text { Skor } \\
\text { Rata- } \\
\text { rata I }\end{array}$ & $\begin{array}{c}\text { Penghargaan } \\
\text { Kelompok }\end{array}$ \\
\hline 1 & 17.14 & Tim baik & 20 & $\begin{array}{c}\text { Tim sangat } \\
\text { baik }\end{array}$ \\
\hline 2 & 20 & $\begin{array}{c}\text { Tim Sangat } \\
\text { baik }\end{array}$ & 22 & $\begin{array}{c}\text { Tim sangat } \\
\text { baik }\end{array}$ \\
\hline 3 & 24.29 & Tim Super & 24.5 & Tim Super \\
\hline 4 & 15 & Tim baik & 23 & $\begin{array}{c}\text { Tim Sangat } \\
\text { baik }\end{array}$ \\
\hline 5 & 15.65 & Tim Baik & 20 & $\begin{array}{l}\text { Tim sangat } \\
\text { baik }\end{array}$ \\
\hline 6 & 16.30 & Tim baik & 19.50 & Tim baik \\
\hline 7 & 16 & Tim baik & 17.69 & Tim baik \\
\hline 8 & 17 & Tim baik & 21 & $\begin{array}{c}\text { Tim Sangat } \\
\text { baik }\end{array}$ \\
\hline
\end{tabular}

Berdasarkan Tabel 3 di atas, hasil penelitian tindakan dapat dinyatakan bahwa terjadi peningkatan keterampilan berbicara dengan menggunakan model kooperatif tipe jigsaw pada siklus I dan siklus II. Secara garis besar, penelitian ini telah berhasil menjawab rumusan masalah yang telah dikemukakan peneliti pada bagian Bab I.

Dari paparan pembahasan di atas dapat ditarik titik kesinambungan terhadap hasil dari penerapan metode jigsaw terhadap peningkatan kemampuan berbicara atau komunikasi siswa. Yaitu di mana siswa mengalami kemajuan dalam mempraktekkan penggunaan bahasa Indonesia yang baik terutama dalam hal komunikasinya yang banyak dilakukan selama proses pembelajaran, baik dengan guru ataupun dengan siswa-siswa lain. Dari sisi aspek kebahasaan ketepatan ucapan, pilihan kata dan ketepatan sasaran pembicaranya meningkat dan lebih baik dari sebelumnya dengan pencapaian ketuntasan belajar sesuai dengan yang di tentukan. Menurut Maidar \& Mukti (1991, p.18) faktorfaktor penunjang keefektivan kegiatan berbicara sebagai berikut: Faktor kebahasaan, meliputi: Ketepatan ucapan, Penempatan intonasi nada, sendi dan durasi yang sesuai, Pilihan kata, Ketepatan penggunaan kalimat serta tata bahasanya, dan Ketepatan sasaran pembicaranya. 


\section{Simpulan dan Saran}

Simpulan

Metode pembelajaran jigsaw dapat meningkatkan keterampilan siswa. Hal tersebut terlihat dari indikator-indikator: (a) keaktifan siswa dalam mengikuti pembelajaran; (b) keberanian siswa untuk tampil di depan kela;, (c) keaktifan kerja sama dengan sesama anggota kelompok; (d) keterampilan berbicara: bertelepon dengan kalimat efektif dan bahasa yang santun. Keberhasilan pembelajaran dapat dilihat dari persentase proses pembelajaran dan keterampilan berbicara. Pada siklus I persentase keberhasilan proses pembelajaran sebanyak (26 siswa) sedangkan pada siklus II meningkat menjadi (29 siswa) dari keseluruhan jumlah siswa (32).

Metode pembelajaran jigsaw dapat meningkatkan kualitas proses pembelajaran di lihat dari tiga aspek penilaian. Hal tersebut terihat dari hasil penelitian berikut ini: (a) Keaktifan siswa dalam mengikuti pembelajaran berbicara pada pelaksanaan siklus I rata- rata kelas pada aspek keaktifan dalam pembelajaran dengan kriteria sangat baik dan sedang yaitu $59 \%$, pada siklus II mengalami peningkatan menjadi $78 \%$ dengan kriteria sangat baik dan baik; (b) Keberanian siswa tampil di depan kelas. Pada siklus I rata-rata kelas dengan kriteria sangat baik dan baik mencapai $50 \%$, dengan kriteria yang sama siklus II mengalami peningkatan menjadi71\%; (c) Keaktifan siswa melakukan kerjasama dengan sesama anggota kelompok. Pada siklus I hasil rata- rata dengan kriteria sangat baik dan baik mencapai $66 \%$, sedangkan pada siklus II dengan kriteria yang sama mengalami peningkatan menjadi $75 \%$.

Saran

Berkaitan dengan simpulan dan implikasi tersebut, diajukan saran sebagai berikut.

\section{Bagi Guru}

Guru harus senantiasa memantau setiap kelompok saat pelaksanaan diskusi berlangsung serta memberikan perhatian dengan mengarahkan agar setiaptahap dalam pelaksanaan metode pembelajaran jigsaw dapat berjalam dengan benar. Dengan melakukan pemantauan guru dapat mengetahui bagaimana kerjasama yang terjalin antar sesama anggota kelompok.

Kegiatan pembelajaran dari awal guru senantiasa memberikan motivasi padasiswa untuk bersungguh- sungguh dalam mengikuti pembelajaran, agar siswa dapat melaksanankan tugas dengan benar. Guru memotivasi siswa untuk berani tampil praktik bertelepon dengan kesadaran sendiri bukan karena ditunjuk oleh guru. Hal ini dilakukan untuk melatih keberanian dan kemandirian siswa serta tanggung jawab terhadap kelompoknya/sesama anggota kelompokya, karena dalam penilaian pembelajaran kooperatif penentuan hasil/nilai berdasarkan nilai individu dalam kelompok. Hal ini berdasarkan salah satu tujuan pembelajaran kooperatif yaitu pertanggung jawaban individual, yang dapat berarti bahwa mencapai keberhasilan kelompok tergantung pada hasil setiap anggota kelompok.

\section{Bagi Sekolah}

Sekolah harus memfasilitasi kegiatan pembelaran, misalnya pada pembelajaran berbicara: bertelepon sekolah menyediakan media yaitu telepon yang digunakan untuk praktik berbicara.

Sekolah harus memfasilitasi kelas dengan adanya media pembelajaran LCD dan komputer atau media yang berupa audio visual sehingga dapat mempermudah guru dalam melaksanakan kegiatan pembelajaran misalnya dalam menjelaskan materi dan memberikan contoh bertelepon. Jadi, siswa tidak hanya mendengarkan tetapi dapat melihat secara nyata dalam tampilan LCD.

\section{Bagi Siswa}

Siswa harus dapat bertanggung jawab dengan keberhasilan kelompoknya, sehingga siswa harus senantiasa bekerja sama saat diskusi maupun saat tampil praktik berbicara di depan kelas.

Siswa harus meningkatkan keberanian dan lebih percaya diri tampil berbicarapraktik bertelepon di depan kelas.

Siswa harus menggunakan kalimat yang efektif dan bahasa yang santun saat bertelepon, dengan mengurangi penggunaan bahasa Ibu (Bahasa Jawa) saat tampil praktik bertelepon di depan kelas.

\section{Daftar Pustaka}

Alek, \& Achmad H.P, (2011). Bahasa Indonesia untuk perguruan tinggi. Jakarta: Kencana

Hermawan, R. (2007). Metode penelitian pendidikan dasar. Bandung: UPI Press. 
Iskandarwassid dan Suhendar, D. (2009). Strategi pembelajaran bahasa Bandung: PT. Remaja Rosdakarya

Jonhson, D.W,. \& Johson, R.T. (2003). Learning together and alone: cooperative, competitive, and individualistic learning. New Jersey: Prantice Hall, Inc.

Kemmis, S \& Taggart, R. (1993). The Action research planner. Victoria: Deaklin University.

Keraf, G. (2004). Komposisi: sebuah pengantar kemahiran berbahasa. Ende: Nusa Indah.

Lie, A. (2002). Cooperative learning: Memraktikkan cooperative learning di ruangruang kelas. Jakarta: Grasindo.

Loudon, D.L. dan Bitta, A.J.D., (1984). Consumer behavior: concept and applications. (Second Editions) New York: McGraw Hill, Inc.

Maidar G. Arsjad dan Mukti US. 1988. Pembinaan kemampuan bicara bahasa Indonesia. Jakarta: Erlangga.

McCaferty, S.G,. Jackob, G.M,. Iddings, A.C.D. (2010). Cooperative learning and second language teaching. Cambridge: Cambridge Language Education.

McPheat, S. (2010). Advance communication skill. MTD Advance \& Ventus Publishing ApS. www. m.t.d. co.uk. diakses tanggal 20 juni 2013.

Moleong ,L. (2002). Penelitian kualitatif. Jakarta: Rosdakarya.

Mulgrave, D. (1954). Speech. New York: Barness \& Noble, Inc.
Nurgiyantoro, B. (2012). Penilaian pembelajaran bahasa Indonesia berbasis kompetensi. Yogyakarta: Anggota IKAPI.

Purwanto, N. (1995). Psikologi pendidikan. Bandung: Remaja Rosdakarya.

QIAO, M.. \& JIN X. (2010). Jigsaw strategy as a cooperative learning technique: focusing on the language learners. Chinese Journal of Applied Linguistics (Bimonthly). Agustus 2010 Vol. 33 No. 4.

Rofi'uddin, A. \& Zuhdi, D. 2001. Pendidikan bahasa dan sastra Indonesia di kelas tinggi. Malang: Universitas Negeri Malang.

Sharma, T.C. (2008). Modern methods of language teaching. Darya Ganj, New Delhi: SARUP \& SONS.

Slavin, R.E. (2009). Psikologi pendidikan dalam Marianto Samosir (terj). Jakarta: PT . Indeks.

Smaldino, E.S., Lowther, D.L., Russell, J.D. (2008). Instructional technology and media for learning. Upper Sadlle River, New Jersey Colombus, Ohio: Pearson Merril Prentice Hall.

Tarigan, H.G,. (2008). Berbicara sebagai suatu keterampilan berbahasa. Bandung: Penerbit Angkasa

Tomkins,Gail E, dan Hoskisson, K. (1995). Language arts. content and teaching strategies. New York: Max well Macmillan International Publishing Group 